\title{
The Hazards of Hindi Catholic Publishing
}

\section{by Clarence Srambical}

"It is easy to become a publisher but difficult to remain one or to remain independent; infant mortality in publishing is higher than in any other trade or profession." Sir Stanley Unwin's remark, though made almost half a century ago in the context of publishing in the United Kingdom, is a useful and pertinent counsel today, especially for Catholic publishers in a developing country like India. This comment ought at least to be considered as a warning by anyone venturing into the field of Hindi Catholic publishing, causing him to stop and reflect on the difficulties he might have to face if he hopes to remain in the publishing business for some time.

This short essay is an attempt to present some of the problems besetting Hindi Catholic publishing, and to suggest possible ways in which they might be overcome by a determined and adventurous publisher.

\section{Lack of Authors}

Publishers need authors. Authors are the source of their basic material, and without them publishing as an industry has no foundation. In the Christian West, as well as in areas of India where the Church has taken deep root for centuries, there is no dearth of able and creative scholars and writers. However, in the Hindi belt of northern India the Catholic Church is in its infancy. The majority of Catholics, like the rest of the population, live in rural areas, and are either semi-literate or illiterate. Approximately 220 million people speak Hindi, and of these only forty-six million are literate. In rural areas the literacy rate is insignificant.

The situation is not much better in cities. The city Catholics are mostly uprooted 'national foreigners' who come from south or western India. Quite a few of them belong to the floating population. Their medium of expression and communication is English, and hardly any can claim to have a mastery of the local language, Hindi.

Even those Catholics who form part of the native population fail to advance in their own language, Hindi, because the education system teaches and encourages English, and perpetuates it in English-medium schools run by Christian institutions. As a result the local Catholics are proficient neither in their own language nor in Hindi. Besides, most Catholics of the area belong to one or other of the tribes or minority communities which have their own ancient languages or dialects. Hindi is a foreign tongue for them too. Consequently they are satisfied with only a smattering of the language. Further, those few who, educated in secular fields and having a good command of the language even to the point of having written books on secular subjects, make no attempt to write on Christian themes. They lack depth in theology and Christian experience.

The Catholic church in Hindi areas is truly a missionary Church. In many places there are no Christians apart from the missionaries themselves. Most of them are either foreigners or 'national-foreigners'. Local vocations to religious, priestly and

P. Clarence Srambical svd erwarb sein Diplom als Verleger vom Polytechnikum Oxford (England); er ist Direktor des Verlages "Satprakashan" in Indore, M.P. (Indien). 
missionary life have been scarce, and those among them who might have a talent for writing are already burdened with other missionary and pastoral duties. As a result there is a dearth of Hindi scholars and writers in the Catholic community.

\section{No Professionalism}

Another related problem is the lack of professionalism among authors. Authors as a species seem to have a firm belief that whatever they write will be bought and read voraciously, irrespective of the fact that their work might be sloppy and contain many inconsistencies. Another characteristic is the author's failure to make up his mind about the public he hopes to attract by his work. Authors frequently have no clear idea of the profile of their readers. Unsolicited manuscripts are usually of poor quality and require much editing. Often authors just do not understand the concept or the usefulness of editing their manuscripts. Seldom do they understand the constructive critical approach of the publisher's readers and editors. Even when the authors see the merit of editing and readers' remarks they fail to acknowledge their indebtedness to these men for making their manuscripts readable. Almost all believe that their books would sell instantly were it not for the want of promotion and publicity by the publisher.

Many Church authors have a wrong idea concerning the publisher. They confuse him with the manager of a printing press. This is due to the history of combining both jobs in one person. In the Indian situation Church personnel have become publishers overnight since it is easier to get funds from abroad. In such a situation it is not at all surprising that authors just do not understand the role and function of a publisher.

Lack of professionalism among authors has resulted partly from a lack of professionalism among publishers themselves. Such being the situation, the responsibility for improving the state of affairs rests on the whole Church in the area. There are now more than 30 dioceses in the Hindi speaking area. The Church has been in the forefront in providing primary and secondary education, but has been slow when it comes to opening professional and technical schools, even showing apathy and a total lack of understanding. No single centre has been established in the region for training professional men required for publishing and allied professions. Even those national institutes such as St. Xavier's Institute of Mass Communications and Media, Bombay, are geared to serve the small English-speaking elite in the Church. Rarely are seminars arranged for encouraging and training Hindi writers and editors. These two problems need to be urgently tackled on a common basis by the whole Church if publishing is to become one of the effective means of evangelisation and total human development. Priority must be given in the dioceses and religious institutes to identify, encourage and train would-be writers, designers, illustrators, editors and publishers. In the Hindi speaking area there is a lack of imagination, of coordinated planning in communication. It is time that bishops and religious superiors set aside some of their local and parochial problems and concentrated their attention on solving wider issues on a global level. This does not mean that nothing is being done by the publishers. Major publishing houses of Ranchi, Allahabad and Indore are already providing in-service training for the men they require immediately. They also publish translations, often using non-Catholics and a team of experts to offset the weakness of individual translators and the shortage of original writers. Individually the publishers may not be in a position to arrange regu- 
lar training courses, but if they come together and cooperate they might be able to pool their resources and expertise to organise a regular specialised course to train men for their profession.

\section{Low standards of production}

Another difficulty which the publishers face in India is in the area of production. Printing with movable type was introduced into India by the Portuguese Jesuits in the sixteenth century, and the first printing press was set up in Goa, India, in 1556. The missionaries were the major publishers and their books mostly religious, liturgical and catechetical works. The first printer in India, a Spaniard, João de Bustamente, is known to have printed five works by 1560 . It is also known that the Portuguese from Goa made a gift of a printing press to the Emperor Akbar around this time, so it can be safely assumed that printing with movable metal type has been in the Hindi speaking region from the sixteenth century3.

Since then the printing and publishing industry has passed through many phases, and it may be generally assumed that many printers and publishers learned their trade in and through the mission printing houses and that most of the published material was of a religious nature for the many Christian missionary groups.

In spite of this, Catholic printing houses, though highly praised locally, have not yet reached the professional quality of international standards apart from a few exceptions. It is true to say that high quality paper is not easily available in India, and if you want to use foreign paper you have to pay exorbitant prices. Many printing presses are run on outdated equipment. The high cost of film means that offset lithography is hardly ever used. The central Government's policy of restricting imports of machinery has adversely affected the kind of equipment available.

However, the main reason for the low quality of production is that publishers have opted for cheap editions and many printing houses are unaware of (or conveniently ignore) international standards. Publishers and printers have assumed until very recently that anything will go with Indian book buyers, so technical standards of many printing presses are poor.

As a result the physical composition of the book is not at all attractive, and the materials used are not strong and durable in terms of paper used, printing and binding. What Monisha Mukudan of Thomson Press (India) Ltd. wrote recently concerning children's books produced in India could be equally applied to Hindi Catholic books: Book design in Indian Children's books is all but non-existent. Even the books put out by the more prestigious publishing houses often look like large pamphlets or worse, like text books gone wrong ${ }^{4}$.

Publishers and printers have sacrificed quality for cheapness. This is the main reason for employing sub-standard designing, editing, sub-editing, printing and binding. However, they are finding out that people are gradually becoming more choosy and beginning to reject books which are badly produced. So it is in the best interests of the publishing and printing industries to cooperate in producing quality books which could be attractive to look at and compete in their own right with any other commodity on the market. 


\section{Shortage of disposable income}

Once the publishers improve the quality of production naturally the prices of books should go up. But since the average disposable income of the people is very low, the pricing of books needs to be carefully evaluated and calculated. Lowering of prices should in no way be at the cost of the quality of illustrations, design and production. Obviously if the publishers take to publishing low-priced books for the mass market they have to find sufficient financial backing. If they are not financially viable they cannot hope to serve the community and be in the market for long.

One way of reducing the initial cost to individual publishers is to plan for co-publication, promotion and distribution of books. Co-publication can be undertaken either on national or regional levels by sharing the original costs.

Another way would be for one publisher to handle the manufacture, then 'selling sheets' to each other if a different language is involved, one publisher buying the artwork or printed illustrated sheets and the second commissioning the printing of the text. Satprakashan in Indore has successfully launched a number of titles as a result of cooperation with other like-minded publishers. For example, 'Inculturation in seminary Formation' is a joint publication of Ishvani (Poona) and Satprakashan (Indore). Recently Satprakashan produced a folder on Brothers, promoting vocations to the brotherhood, the text of which is to be printed at several places in India. As a result the initial capital investment is shared among the parties concerned and no single publisher has to bear the whole burden. Cooperation and collaboration can also be achieved by buying paper in common and promoting books. This might well be a topic to be discussed when Hindi publishers meet in 1980.

\section{Promotion and Publicity. Distribution Outlets.}

The weakest spot in Hindi Catholic publishing is the general lack of promotion and distribution outlets. There are no Catholic dailies, weeklies or monthlies serving the whole region. Consequently there is no way of reaching the readers of the region through advertisements in such publications. The entire region lacks sufficient bookshops, libraries and institutions.

At present the main promotion is done through mail-order catalogues sent to mission stations, parishes and religious houses. Though this has advantages, not every parish priest or religious superior is prompt to act on receiving the mail-order catalogue. If it is laid aside it is as good as forgotten, and an order is lost. Very few parishes or stations have their own libraries or bookshops, and not many missionaries have books among the priorities on their shopping list. Consequently a great deal of education is required to create an atmosphere in which such facilities could grow. In this task Bishops, religious superiors and the leading publishing houses have an active part to play.

\section{Conclusion: A Ray of Hope}

The ray of hope for the Hindi Catholic publishing comes from the publishers of the region themselves. They are more than ever aware of the need for cooperation and collaboration. No doubt there will be some competition, and fair competition among the leading publishers would benefit both the people of the region and the publishing business. However, efforts are being made to avoid competition as far as possible on titles which are commonly needed in the region. 
The Bishops too have been coming together to draw up plans to encourage Hindi Catholic literature. Recently they appointed a three-member Bishops' Commission to do just that. If the Bishops and major superiors of religious congregations can stimulate and encourage the men in the field, much can be achieved by way of cooperation and collaboration. Publishing has always been essentially a cultural, intellectual and religious activity which helps to bring the products of creative authors and artists to the attention of a particular audience, inspiring it to study those products, and finally make it want to possess them. By coordinating the activities of authors and artists, designers and printers, book sellers and book readers in the pursuit of information, knowledge, culture and religious experience, the publishers play a key role in advancing evangelisation and total human development.

The challenge these difficulties pose in the Hindi region is not without risks in the publishing industry of the area, but it also offers creative opportunities for a publisher with imagination.

\section{Notes}

1 Unwin, Philip: The Truth About Publishing, Eighth Edition, 1976, p. 15

2 Kanjamala, Augustin: Religion and Modernization, 1978, p. 223.

${ }^{3}$ Hasan, Abul: Indian Book Industry - Some Salient Features. In: Indian Book Industry, Vol. XIV, No. 586, Aug.-Sept. 1976, p. 43.

${ }^{4}$ Mukudan, Monisha: 'Book Design in Indian Children's Books'. In: Indian Book Industry, Vol. XVI, No. 1, April 1977, p. 17.

\section{ZUSAMMENFASSUNG}

Welche Schwierigkeiten hat ein Verleger, der katholische Bücher in Hindi veröffentlichen möchte und wie kann er die damit sich ergebenden Probleme lösen? Verleger brauchen Autoren: ohne Menschen, die schreiben, kann der beste Verlag nicht existieren. In mehrheitlich christlichen Gegenden dürfte es nicht so schwer sein, Autoren zu finden, aber im Hindisprachgebiet Nordindiens ist die Kirche eine sehr kleine Minderheit, und die meisten Katholiken leben in ländlichen Gegenden. Im übrigen können sie wie die meisten Bewohner dieser Gebiete kaum oder gar nicht lesen. Von rund 220 Millionen hindisprachigen Einwohnern Nordindiens können nur etwa 46 Millionen lesen. Auch sind die Katholiken in den Städten meistens „nationale Ausländer”, d.h. sie stammen etwa aus dem Süden oder Westen Indiens und haben of Englisch, aber nicht Hindi als ihre Muttersprache. Hinzu kommt, daß die Ausbildung Englisch bevorzugt, und auch die Missionsschulen sind oft englischsprachig ausgerichtet. Auch Mitglieder von Minoritäten und kleineren Stämmen haben oft ihre eigene Sprache, und so bleibt Hindi für die meisten mehr oder weniger fremd. So gibt es nur wenige katholische Autoren, die wirklich gut in Hindi schreiben können, und diese sind dann meist völlig überlastet. 
Verbunden mit dieser Schwierigkeit ist auch der Mangel an klaren Vorstellungen über die Zielgruppe hindisprachiger Publikationen. Unverlangte Manuskripte sind meist von geringer Qualität und schlecht redigiert. Jeder Autor glaubt, seine Bücher verkaufen sich von selbst. Meist sieht man vor allem auch in kirchlichen Kreisen nicht die Rolle und Bedeutung des Verlegers für die Gestaltung und Vermarktung eines Buches. Die Verwechslung zwischen einem Drucker und Verleger ist in der Kirche üblich. In der indischen Situation sind kirchliche Verantwortliche über Nacht zu Verlegern geworden, weil es einfacher zu sein scheint, für die Veröffentlichung von Büchern finanzielle Hilfe vom Ausland zu bekommen, kirchliche Verleger selbst haben weithin keine Fachausbildung. In Indien bestehen jetzt mehr als 30 hindisprachige Diözesen. Im Unterhalt von Grund- und Hauptschulen leistet die Kirche Pionierarbeit, aber bei weiterführenden Schulen versandet diese Aktivität schnell.

Es gibt in der ganzen Region auch keine Ausbildungsstätte für publizistische Beru$\mathrm{fe}$, und die wenigen Möglichkeiten, welche anderswo im Lande bestehen, wie z.B. in St. Xavier's, in Bombay, dienen mehr der englischsprechenden Bevölkerung. Fortbildungskurse für Autoren und Redakteure in Hindi sind höchst selten.

Die wichtigste Aufgabe ist das Entdecken und die Heranbildung von Autoren, Redakteuren, Graphikern und Verlegern. Die bestehenden Verlagshäuser in Ranchi, Allahabad und Indore versuchen ihr Bestes durch eine innerbetriebliche Ausbildung zu leisten. Aber gemeinsame Initiativen würden hier auch weiter führen.

Auch die technische Schwierigkeit bleibt. Obwohl die ersten Druckereien, wie etwa in Goa 1556, von Missionaren in Indien eingeführt wurden und viele Drucker auch heute noch durch Missionsdruckereien ausgebildet wurden, entspricht mit wenigen Ausnahmen die Druckqualität der christlichen Druckereien nicht dem internationalen Standard. Allerdings haben hier wohl auch die Importbeschränkungen der Regierung einen Einfluß, und im übrigen kennt der Kunde keinen internationalen Maßstab: er kauft, was gerade vorhanden ist. Wenn gesagt wird, daß es etwa für indische Kinderbücher praktisch kein Buchdesign gibt, dann gilt das auch für katholische Publikationen.

Eine Verbesserung der Bücher macht sie allerdings auch teurer. Die Kaufkraft der Kunden ist aber so gering, daß nur eine scharfe Kalkulation zu einem annehmbaren Preis führt, wobei die Qualität nicht vermindert werden sollte. Dafür braucht der Verleger aber andererseits auch ein gewisses finanzielles Polster. Gemeinschaftsproduktionen, gemeinsame Werbung und Vertrieb können hier helfen.

Die schwächste Seite der Hindi-Verlagsarbeit ist der Mangel an Werbe- und Vertriebsmöglichkeiten. Es gibt keine katholischen Zeitungen, Wochen- oder Monatszeitschriften in Hindi, die im ganzen Sprachgebiet verbreitet sind. Wie soll man also die potentiellen Leser erreichen? Auch Buchhandlungen, Bibliotheken und Lesesäle gibt es kaum. So bleibt nur der Versand von Prospekten und die Belieferung durch die Post an Missionsstationen, Pfarrhäuser oder religiöse Gemeinschaften.

Die Verleger der Region aber sind sich wachsend ihrer Situation und der Aufgabe zur Zusammenarbeit bewußt. Auch die Bischöfe sehen die Bedeutung christlicher Hindi-Literatur; sie haben gerade eine Kommission ernannt, die nach Wegen und Mitteln suchen und eine entsprechende Struktur aufbauen soll. 


\section{RÉSUME}

Un éditeur qui veut publier des livres catholiques en Hindi a de grosses difficultés. Dans la région linguistique Hindi du nord de l'Inde, l'Eglise est une minorité paysanne, en grande partie analphabète et souvent linguistiquement orientée vers l'anglais. Des manuscripts présentés spontanément sont la plus souvent de qualité médiocre. Les éditeurs écclésiastiques sont encore sans formation professionelle. Dans la région, il n'y a encore aucun centre de formation pour les métiers de la publicistique. Pour cela, il est important de découvrer les auteurs, les rédacteurs, les dessinateurs et les éditeurs, et de les former. Cependant, il reste également de grosses difficultés techniques, telles qu'un grand manque de possibilités de publicité et de vente. Le fait que les éditeurs de la région soient conscients de leurs situation, que les évèques aient pris conaissance de la signification de l'écriture chrétienne Hindi et qu'ils aient nommé une commission d'encouragement correspondante, tout cela éveille de nouveaux espoirs.

\section{RESUMEN}

Cuando un editor quiere publicar libros católicos en lengua indostaní del norte de India la iglesia local es minoritaria, analfabeta en parte y a menudo sus conocimientos se limitan al inglés. Los manuscritos no solicitados son casi siempre de escasa calidad. Con frecuencia los editores eclesiásticos no tienen formación adecuada. No existe en la región centro algunode formación publicística. Por ello es importante el descubrimiento y la formación de autores, redactores, impresores y editores. Pero incluso entonces habrá grandes problemas técnicos y se troperazará con la falta de posibilidades de publicidad y comercialización. Los editores de la zona van siendo conscientes de su situatión. También los obispos descubrieron la importancia de escritos cristianos en indostani y crearon la correspondiente comisión de promoción. Todo ello despierta nuevas esperanzas. 